\title{
Journal of Bioresource Management
}

\section{Survey of human-leopard (Panthera Pardus) conflict in Ayubia National Park, Pakistan}

Muhammad Nabeel Awan

Government College University Lahore, nabeelawan120@gmail.com

Atif Yaqub

Government College University Lahore, atif@gcu.edu.pk

Muhammad Kamran

Quaid-e-Azam university Islamabad, kymzgc@gmail.com

Follow this and additional works at: https://corescholar.libraries.wright.edu/jbm

Part of the Animal Sciences Commons, and the Biology Commons

\section{Recommended Citation}

Nabeel Awan, M., Yaqub, A., \& Kamran, M. (2020). Survey of human-leopard (Panthera Pardus) conflict in Ayubia National Park, Pakistan, Journal of Bioresource Management, 7 (2).

DOI: https://doi.org/10.35691/JBM.0202.0130

ISSN: 2309-3854 online

(Received: May 4, 2020; Accepted: ; Published: Jun 1, 2020)

This Article is brought to you for free and open access by CORE Scholar. It has been accepted for inclusion in Journal of Bioresource Management by an authorized editor of CORE Scholar. For more information, please contact library-corescholar@wright.edu. 


\section{Survey of human-leopard (Panthera Pardus) conflict in Ayubia National Park, Pakistan}

(C) Copyrights of all the papers published in Journal of Bioresource Management are with its publisher, Center for Bioresource Research (CBR) Islamabad, Pakistan. This permits anyone to copy, redistribute, remix, transmit and adapt the work for non-commercial purposes provided the original work and source is appropriately cited. Journal of Bioresource Management does not grant you any other rights in relation to this website or the material on this website. In other words, all other rights are reserved. For the avoidance of doubt, you must not adapt, edit, change, transform, publish, republish, distribute, redistribute, broadcast, rebroadcast or show or play in public this website or the material on this website (in any form or media) without appropriately and conspicuously citing the original work and source or Journal of Bioresource Management's prior written permission. 


\title{
SURVEY OF HUMAN-LEOPARD (PANTHERA PARDUS) CONFLICT IN AYUBIA NATIONAL PARK, PAKISTAN
}

\author{
MUHAMMAD NABEEL AWAN ${ }^{1}$, ATIF YAQUB ${ }^{1}$ AND MUHAMMAD KAMRAN ${ }^{2}$ \\ ${ }^{1}$ Government College University, Lahore \\ ${ }^{2}$ Quaid-e-Azam University, Islamabad \\ * Corresponding author: nabeelawan120@gmail.com
}

\begin{abstract}
Wildlife populations are at a risk of extinction mainly because of human-wildlife conflict (HWC). The present study was designed to evaluate the ongoing HWC with special reference to Common Leopard (Panthera pardus) in Ayubia National park through field study as well as a literature-based approach. Questionnaire interview surveys were designed for wildlife officials working in the park and the locals who bear the cost for leopard conflict through livestock depredation and crop damage. The study showed that human-leopard conflict in the study area has been increasing. More than $60 \%$ of people considered livestock depredation as the major reason for their negative perception towards the common leopard. Among livestock, goats were more vulnerable which showed that leopards mostly preferred smaller prey. A number of reported human injuries and deaths on account of Human-Leopard conflict in the study area helped conclude that human-wildlife conflict is a significant issue. Mitigation measures may hence be recommended, such as livestock compensation schemes and community-based conservation approaches, etc. It is critical to avoid human-Leopard conflict not only to keep the public and their property safe but also to help conserve this important species of common leopard (Panthera pardus).
\end{abstract}

Key words: Panthera pardus, wildlife, conflict, leopard, Ayubia

\section{INTRODUCTION}

Wildlife is a precious biological resource of the ecosystem, which is at stake particularly on account of anthropogenic activities (Manfredo, 2008; Bagchi and Mishra, 2006). More so recently as technological development by human society, rapidly growing human population and overwhelming trend of urbanization have made the situation even worse. Recently, careful investigations have suggested that wildlife resource is at risk mainly because of human-wildlife conflict (HWC) more than any other possible factor (Bennett and Robinson, 2000; Li et al. 2013; Bibi et al. 2013).

Human-wildlife conflict (HWC) occurs when the needs and/or behavior of wildlife impact negatively on the goals of humans and vice versa (Madden, 2004; Chattha et al. 2013; Dar et al. 2009). Large carnivores are particularly involved in conflict because of their large home ranges and feeding requirements that mostly overlap with people (Redpath et al., 2001; Khorozyan et al. 2018). These species are forced to live alongside humans and they have to compete for space and prey species (Partasasamita et al. 2016; Bhatia et al. 2013). HWC is now widespread than ever before and has even emerged as a major challenge in the arena of conservation biology (Pandey et al. 2016; Wasim et al. 2014). Conflict between humans and wildlife is now more widespread than ever before and has emerged as a major challenge in the arena of conservation biology (Farrington et al. 2019). In other words, HWC is an important issue to be taken into account for the management of wildlife resource management and growing human needs (Naha et al. 2018; Shehzad et al. 2015; Ahmad et al. 2007). 
The status of leopard (Panthera pardus) population in Ayubia national park clearly illustrates the ongoing situation of human-wildlife conflict involving carnivore species in Pakistan (Afza et al. 2018; Asad et al. 2019; Hussain et al. 2019). It was once widely distributed in this park as well as other regions of the country which were considered hotspots for leopards but they have been persecuted on a large scale especially due to increasing level of conflict with the local communities (Ahmad et al. 2016; Kshettry et al. 2017; Hussain, 2003). The issue of humanleopard conflict remains a priority issue for wildlife department because of the intense pressure from the local communities which are continuously complaining about their livestock losses due to leopard and other carnivore species (Lovari \& Mishra, 2016; Mishra, 2003; Asad et al. 2019).

The study investigates the current situation of human-leopard conflict in Ayubia national park along with the methods and techniques adopted by the villagers to mitigate conflict. Attitude of people towards leopard conservation was also investigated.

\section{MATERIALS AND METHOD}

\section{Study Area}

Ayubia National park is spread over an area of 33 square kilometers with the surrounding forests which cover an area of 150 square kilometers. Sub-alpine meadows, alpine meadows and subtemperate forests comprise the park (Ahmad et al., 2007). The park experiences an average rainfall between $1065 \mathrm{~mm}$ and $1424 \mathrm{~mm}$ and average snowfall around 1$2.5 \mathrm{~m}$.

\section{Field Study}

From November, 2018 to April, 2019, four random visits were made to
Ayubia National Park and the data was generated through following methods:

- Indirect observation

- Questionnaire surveys and group interviews

- Human wildlife depredation surveys

- Consultation with leopard experts

\section{Indirect Observation}

To evaluate the indirect presence of Common Leopard, the selected area was explored to find the evidence of species in the form of pug marks, scats, claws marks and feeding material. Attempt was also made to directly observe the Common Leopard.

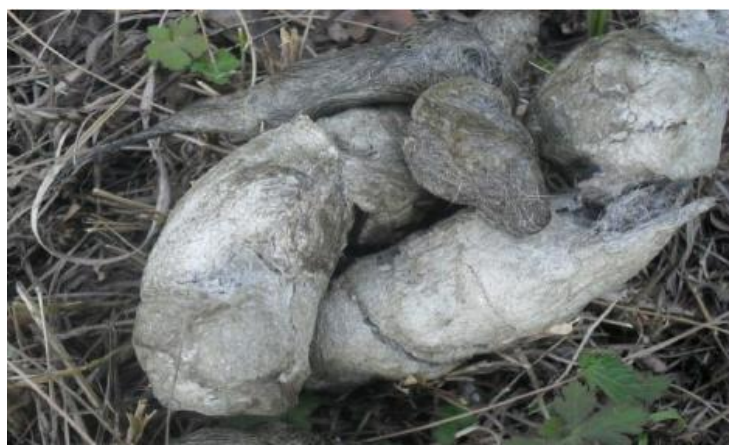

Figure 1. Fecal matter of common leopard at study site (Ayubia National Park)

\section{Questionnaire Surveys}

Structured and unstructured interviews and participatory observations were done with the wildlife officials and local communities holding a considerable number of livestock. Questionnaire surveys and observations to assess the occurrence and distribution of predators were used. The questionnaire survey was done using Likert type of frequency scale. Three wildlife officials from Ayubia National Park were interviewed to collect information (Table 1). 
Assessment of livestock killing and attacks was done by developing a simple but comprehensive questionnaire survey from the local community especially shepherds. Carnivore attacks were divided into two categories: conflict cases inside community areas and conflict cases in leopard habitat. People interviewed were mostly old males who have dependency, primarily on livestock. The potential sites were visited and local people were interviewed to collect direct information. Semi-structured interviews used a combination of formal and open- ended questions.

A community survey was done to evaluate the type of livestock affected by common leopard in the area. People were also asked if they are using any technique or safety method to reduce wildlife conflict on their own effort. It was used to assess whether people were aware of protective measures or if they just wanted to eliminate leopard population from their area.

A general inference in the form of yes or no was received first and then locals who were using protective measures were further questioned about the type and effect of their adoptive methods.

\section{Community Survey}

A survey on livestock depredation was conducted mainly using bipolar questions with the help of a questionnaire (Table 2). Fifty participants took part in this survey.

\section{Collection of Secondary Data}

The secondary data was collected through previously published literature. Then a meta-analysis was done to compare the current status of human-leopard conflict with the past studies on this subject.

\section{Graphical Analysis}

The numerical or quantitative data was then put into a more comprehensive form using a graphical approach by using MS Excel.

\section{RESULTS}

Response of the three wildlife officials in the questionnaire survey based on Likert scale (Table 1). 
Table 1. Response of wildlife officials in Ayubia National Park

\begin{tabular}{|c|c|c|c|c|c|c|c|c|c|c|}
\hline \multirow{2}{*}{ Sr. } & \multirow{2}{*}{ Questionnaire } & \multicolumn{3}{|c|}{ Respondent 1} & \multicolumn{3}{|c|}{ Respondent 2} & \multicolumn{3}{|c|}{ Respondent3 } \\
\hline & & 1 & 2 & 3 & 1 & 2 & 3 & 1 & 2 & 3 \\
\hline 1 & $\begin{array}{l}\text { Are you agreed that Human leopard conflict in } \\
\text { study area has increased? }\end{array}$ & & & & & & & & & \\
\hline 2 & $\begin{array}{c}\text { Common leopard has become a major threat for } \\
\text { livestock? }\end{array}$ & & & & & & & & & \\
\hline 3 & $\begin{array}{l}\text { Common leopard population in the study } \\
\text { area has increased? }\end{array}$ & & & & & & & & & \\
\hline 4 & $\begin{array}{l}\text { Is local's attitude towards common leopard is } \\
\text { important in relation to human wildlife conflict? }\end{array}$ & & & & & & & & & \\
\hline 5 & $\begin{array}{c}\text { Negligence of shepherds is also involved in } \\
\text { increasing livestock attacks? }\end{array}$ & & & & & & & & & \\
\hline
\end{tabular}

1(Strongly agree), 2 (Agree), 3(Disagree)

\section{Protective Measures Adopted by Locals}

Some local people are using technique against the wildlife conflict, but mostly people were not familiar with any tools and techniques to mitigate humanwildlife conflict in study area. There, $32 \%$ of total respondents were familiar and using techniques against the wildlife conflict and $68 \%$ of total respondents had no any information regarding conflict and its mitigating tools (Figure 2).

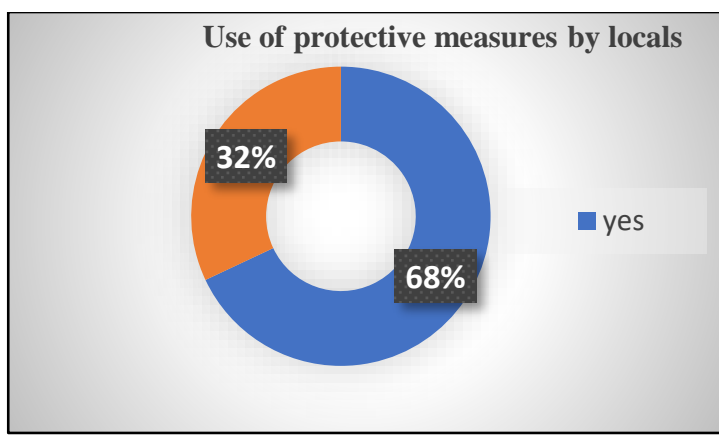

Figure 2. Response of locals in using protective techniques

Table 2. Community survey based on questionnaire

\begin{tabular}{|c|c|c|}
\hline Questionnaire & $\begin{array}{c}\text { Response 1= } \\
\text { YES }\end{array}$ & $\begin{array}{c}\text { Response } \\
\text { 2=NO }\end{array}$ \\
\hline Did you see Common Leopard frequently moving in this area? & $40 \%$ & $60 \%$ \\
\hline Is Common Leopard being the key specie which attack your livestock? & $78 \%$ & $22 \%$ \\
\hline Do you think that Common Leopard population is declining? & $43 \%$ & $57 \%$ \\
\hline Are the attacks by leopard are common when livestock is grazing? & $50 \%$ & $50 \%$ \\
\hline Do you consider Common Leopard, an enemy species? & $90 \%$ & $10 \%$ \\
\hline Did you see dead leopard around? & $32 \%$ & $78 \%$ \\
\hline Are park animals being problem for you? & $62 \%$ & $38 \%$ \\
\hline
\end{tabular}




\section{Killing of Common Leopard in Ayubia National Park}

As we collected data from officials and we found that around 20 leopard killings have been reported from Khyber Pakhtunkhwa (KPK) specially in Galiat region around Ayubia National park from 2011 to 2017. In 2005, 5 leopards were killed and in 2006 and 2007, 8 human-caused killings were reported. In 2013, 2 leopard killings were reported.

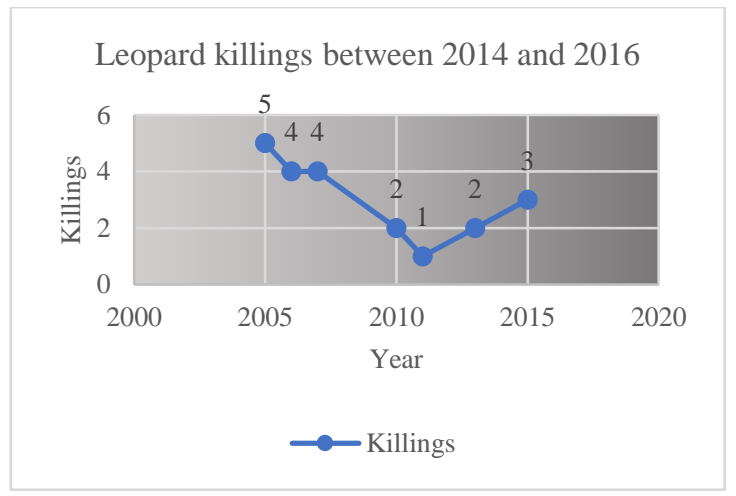

Figure 3. Number of Leopards killed between 2004 and 2016

\section{Type of Livestock Killed}

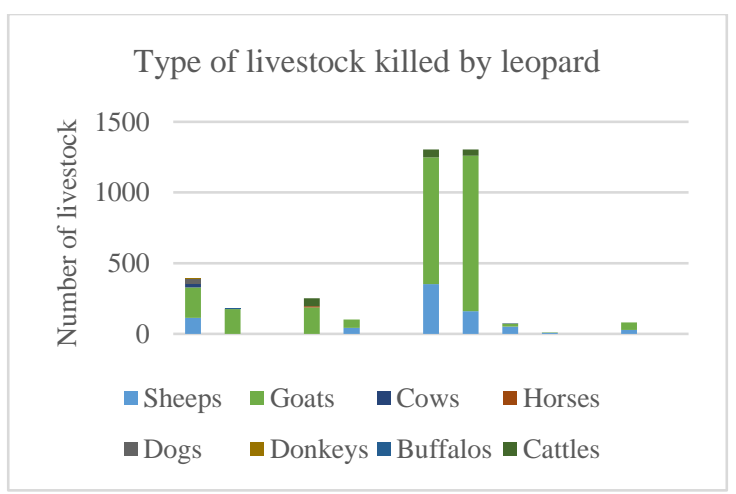

Figure 4. Type of livestock killed by Common Leopard

\section{Human Injuries by Wildlife}

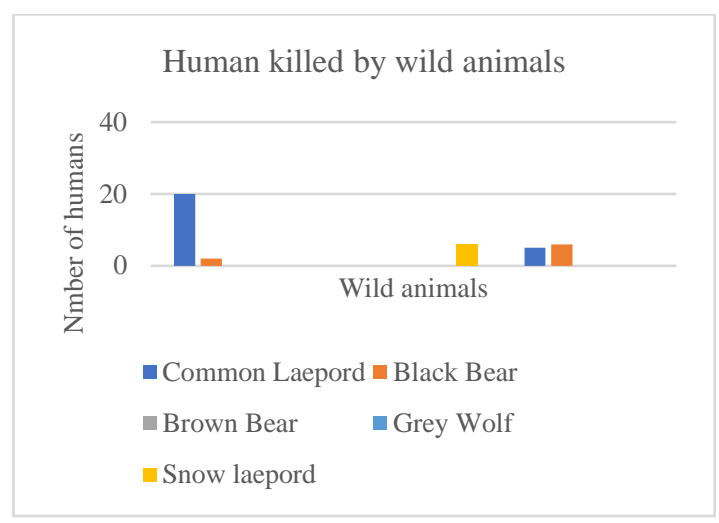

Figure 5. Human injuries caused by different wild species

\section{DISCUSSION}

Human-wildlife conflict is not a new issue in the field of wildlife management. However, the methods for handling carnivore related problems remained unique and distinct depending upon each specie depending upon time, area and resources. According to (Kabir et al., 2014), recent increase in attacks on human by common leopard has led me to consider specie-specific management practices which come into limelight after considering previous drawbacks in the field studies of wildlife management. In the same way, our study also founded an adjoining link between better wildlife management practices and decreased cases of human-wildlife conflict. The study enables me to suggest management actions in broader sense to achieve ultimate goals of leopard conservation and management. High density of human settlements in leopard country perhaps negatively affected habitat quality and increased depredation incidents in Ayubia National park (Khanum and Gilani, 2005). Reserved forest in Galiat consist of leopard habitat and any operation can adversely affect the habitat. If the reserved forest is included in national park it will provide good habitat for leopard. 
Of all the livestock affected by wildlife, our study has indicated that donkeys and dogs are the most affected. Sheep, goats and cows are also among preyed animals by common leopard. Similarly, a study conducted by (Sange and Vernes, 2008) also showed that horses are the most affected animals among the preyed species by wildlife animals in Bhutan. So, it inferred that the predation by wildlife depends on the abundance of livestock which is present in a certain area. In our study area, stray dogs and donkeys are more common, hence, they are mostly preyed by leopard; sheep and cattle are under protection of owners; they are among the least affected.

Our study has indicated that among the mammalian carnivores, common leopard is causing more injuries to human beings, followed by brown bear and snow leopard. This phenomenon is possibly due to the presence of more leopard species in vicinity of human population as compared to other carnivore species. Urbanization and deforestation have damaged natural habitat of wildlife species and there is growing trend of human-wildlife conflict in these areas. Contrary to this, snow leopard is less exposed to human population and most of the conflict cases were in preying areas rather than in vicinity of urban areas.

Protective measures to avoid conflict and damage with leopard are adopted by $68 \%$ of people in our study area. Similarly, (Shakeel et al., 2016; Dar et al., 2009) also reported scarcity of protective measures adopted by the locals. Also, the response of locals towards the understanding of human wildlife conflict was poor as it is evident from our questionnaire survey with locals in Ayubia National Park. Leopard tends to be a solitary and nocturnal hunter, relying on stealth and camouflage to stalk up close to their prey (Rabinowitz, 1989). It was therefore unsurprising that livestock in villages were particularly vulnerable at night, as they were often left unattended and in poorly constructed pens.
Leopard predation reports on livestock were collected throughout the study area to document intensity of predation (Distefano, 2005). Two other predators Red fox (Vulpus vulpus) and Asiatic Black bear (Ursus thibetanus) also exist in the study area, therefore we ensured that the recorded predations are caused only by leopard. In our study we found a large number of human-leopard conflicts in Ayubia national park and the harsh attitude of people towards wildlife was also found.

\section{REFERENCES}

Afza R, Ahmad, H, Saqib Z, Marwat KB and Khan J (2018). Spatial analysis of vascular flora of ayubia national park, KPK, Pakistan: a classical example of moist temperate himalaya. Pak J Bot., 50 (4):14991508.

Ahmad S and Javed S (2007). Exploring the economic value of underutilized plant species in Ayubia National Park. Pak J Bot., 39 (5): 1435-1442.

Ahmad S, Hameed S, Ali H, Khan TU, Mehmood $\mathrm{T}$ and Nawaz MA (2016). Carnivores' diversity and conflicts with humans in Musk Deer National Park, Azad Jammu and Kashmir, Pakistan. Eur J Wildl Res., 62 (5): 565-576.

Asad M, Waseem M, Ross JG and Paterson AM (2019). The un-common leopard: Presence, distribution and abundance in Gallies and Murree Forest Division, Northern Pakistan. Nat Conserv., 37: 53-80. https://doi.org/10.3897/natureconse rvation. 37.32748 .

Bagchi S and Mishra C (2006). Living with large carnivores: predation on livestock by the snow leopard (Uncia uncia). J Zool., 268 (3): 217-224.

Bennett EL and Robinson JG (2000). Hunting of wildlife in tropical forests: implications for biodiversity and forest peoples. Environment Department working 
papers; no. 76. Biodiversity series. Washington, D.C.

Bhatia S, Athreya V, Grenyer R and Macdonald DW (2013). Understanding the role of representations of human-leopard conflict in Mumbai through mediacontent analysis. Conserv Biol., 27 (3): 588-594.

Bibi SS, Minhas R.A, Awan MS, Ali U, and Dar NI (2013). Study of ethnocarnivore relationship in Dhirkot, Azad Jammu and Kashmir (Pakistan). J Anim Plant Sci., 23: 854-859.

Chattha SA, Iqbal S, Rasheed Z, Razzaq A, Husain M and Abbas MN (2013). Human-leopard conflict in Machiara National Park (MNP), Azad Jammu and Kashmir (AJK), Pakistan. Pak J Zool., 47 (1): 222228.

Dar NI, Minhas RA, Zaman Q and Linkie M (2009). Predicting the patterns, perceptions and causes of humancarnivore conflict in and around Machiara National Park, Pakistan. Biol Conserv., 142 (10): 2076-2082.

Distefano E (2005). Human-Wildlife Conflict worldwide: collection of case studies, analysis of management strategies and good practices. Food and Agricultural Organization of the United Nations (FAO), Sustainable Agriculture and Rural Development Initiative (SARDI), Rome, Italy. Available from: http://www. Fao. Org/documents.

Farrington JD and Tsering D (2019). Human-snow leopard conflict in the Chang Tang region of Tibet, China. Biol Conserv., 237: 504513.

Hussain A, Mahmood T, Akrim F, Andleeb S, Fatima H, Hamid A and Waseem M (2019). Depleting wild prey compels common leopard (Panthera pardus) to sustain on livestock. Anim Biol., 69 (2): 213230.

Hussain S (2003). The status of the snow leopard in Pakistan and its conflict with local farmers. Oryx, 37 (1), 26-33.

Kabir M, Ghoddousi, A, Awan MS and Awan MN (2014). Assessment of human-leopard conflict in Machiara National Park, Azad Jammu and Kashmir, Pakistan. Eur J Wildl Res., 60 (2): 291-296.

Khan SR and Naqvi A (2000). Indigenous Rights and Biodiversity Conservation: A Case Study of Ayubia National Park. Sustainable Development Policy Institute. Retrieved from: https://www.eldis.org/document/A 70224

Khanum R and Gilani S A (2005). Conservational status of plant seedlings in Ayubia National Park, Pakistan. Lyonia [Online] J Ecol., 8 (1): 51-60.

Khorozyan I, Ghoddousi S, Soufi M, Soofi $M$ and Waltert M (2018). Cattle selectivity by leopards suggests ways to mitigate human-leopard conflict. Ecol Evol., 8 (16): 80118018.

Kshettry A, Vaidyanathan S and Athreya V (2017). Leopard in a tea-cup: A study of leopard habitat-use and human-leopard interactions in north-eastern India. Plos One: 12(5).

Li J, Yin H, Wang D, Jiagong Z and Lu Z (2013). Human-snow leopard conflicts in the Sanjiangyuan Region of the Tibetan Plateau. Biol Conserv., 166: 118-123.

Lodhi A (2007). Conservation of leopards in Ayubia National Park, Pakistan. Graduate Student Theses, Dissertations, \& Professional Papers., 238. Retrieved from: https://scholarworks.umt.edu/etd/2 38 
Lovari S and Mishra C (2016). Living on the edge: depletion of wild prey and survival of the snow leopard. In: Snow Leopards. Academic Press: pp. 69-76.

Madden F (2004). Creating coexistence between humans and wildlife: global perspectives on local efforts to address human-wildlife conflict. Hum Dimens Wildl., 9 (4): 247-257.

Manfredo MJ (2008). Who cares about wildlife? In: Who Cares About Wildlife., pp. 1-27.

Mishra C, Allen P, Mccarthy TO, Madhusudan MD, Bayarjargal A and Prins HH (2003). The role of incentive programs in conserving the snow leopard. Conserv Biol., 17 (6): 1512-1520.

Naha D, Sathyakumar S and Rawat GS (2018). Understanding drivers of human-leopard conflicts in the Indian Himalayan region: Spatiotemporal patterns of conflicts and perception of local communities towards conserving large carnivores. Plos one: 13 (10).

Pandey P, Sharma V, Singh SK, Goel D and Goyal SP (2016). Curtailing human-leopard conflict using wildlife forensics: A case study from Himachal Pradesh, India. J. Forensic Sci., 7:1-4.

Partasasmita R, Shanida SS, Iskandar J, Megantara EN, Husodo T, Parikesit $P$ and Malone N (2016). Human-
Leopard Conflict in Girimukti Village, Sukabumi, Indonesia. Biodivers J Biol Divers., 17 (2): 5-8.

Rabinowitz A (1989). The density and behaviour of large cats in a dry tropical forest mosaic in Huai Kha Khaeng Wildlife Sanctuary, Thailand. Nat Hist Bull Siam Soc., 37: 235-251.

Redpath SM, Young J, Evely A, Adams WM, Sutherland WJ, Whitehouse A, Amar A, Lambert RA, Linnell JD, Watt A and Gutierrez RJ (2013). Understanding and managing conservation conflicts. Trends Ecol Evol., 28 (2): 100-109.

Sangay T and Vernes K (2008). Humanwildlife conflict in the Kingdom of Bhutan: patterns of livestock predation by large mammalian carnivores. Biol Conserv., 141 (5): 1272-1282.

Shehzad W, Nawaz MA, Pompanon F, Coissac E, Riaz T, Shah SA and Taberlet P (2015). Forest without prey: livestock sustain a leopard Panthera pardus population in Pakistan. Oryx, 49 (2): 248-253.

Wasim S, Nawaz MA, Pompanon F, Coissac E, Riaz T, Shah SA and Taberlet P (2014). Forest without prey: livestock sustain a leopard Panthera pardus population in Pakistan. Oryx, 49 (2): 1-6. DOI: 10.1017/S0030605313001026. 